Anna Janus (iD https://orcid.org/0000-0001-9693-0429

University of Wrocław, Imago Foundation in Wrocław

Agnieszka Pawłowska

Imago Foundation in Wrocław

\title{
Respite care services in Poland - a new quality of social services in Poland
}

\author{
https://doi.org/10.25312/2391-5110.14/2019_01ajap
}

\begin{abstract}
Summary
This article presents some of the first experiences of introducing respite care in Poland. The authors analyse the requirements of the service and its availability in Polish local authority areas. The "Respite Care Programme" appeared in Poland in 2019'. It gave Polish local authorities, for the first time, the opportunity to take advantage of solutions that have been implemented in Western democracies for many years. Drawing on their research, the authors analyse the problem in a substantive and practical way.
\end{abstract}

Keywords: social policy, people with disabilities, carers of people with disabilities, local services, respite care (short break)

\section{Usługa opieki wytchnieniowej w Polsce - nowa jakość usług socjalnych w Polsce}

\section{Streszczenie}

Artykuł przedstawia pierwsze doświadczenia związane z wprowadzeniem usługi przerwy wytchnieniowej w Polsce. Autorki dzielą się swoimi refleksjami w odniesieniu do analizy potrzeb i dostępności usługi w polskich samorządach. Program opieki wytchnieniowej pojawił się w Polsce w 2019 roku i pozwolił na wdrożenie rozwiązań

\footnotetext{
${ }^{1}$ Program „Opieka wytchnieniowa” 2019.
} 
stosowanych w demokracjach zachodnich. Autorki analizują problem pod kątem merytorycznym, ale także praktycznym, odnosząc się do przeprowadzonych badań.

Słowa kluczowe: polityka socjalna, osoby z niepełnosprawnością, opiekunowie osób z niepełnosprawnością, usługi lokalne, opieka wytchnieniowa

\section{Introduction}

Policies for families with a disabled person requiring care is a public policy area that has become the subject of public debate in recent years thanks to grassroots social mobilisation of direct stakeholders. However, policy focuses on providing support to people who leavepaid work in order to provide care for loved ones, but ignorescarers' other needs ${ }^{2}$. This is not surprising, because many areas of social policy - both local and national - are not preceded by a sufficient assessment of needs.

Local social policy, created and implemented by local government on a local and regional scale, is an important element of social policy and, in some areas, the only way to influence the situation of the inhabitants of a given area. The fact that selected cases were handed over to local self-government institutions is the result of progressive decentralisation in the functioning of the state, which is reflected in the Constitution and, above all, the principle of subsidiarity declared in the Preamble to the Constitution. Thisstrengthens the rights of citizens and their communities. The subsidiarity principle implies a division of tasks between citizens and their communities - various social organisations, foundations and other entities - and the state. Tasks which are more complicated or impossible to implement at the local or regional level are allocated to the state ${ }^{3}$.

Respite care is well-established in the support system for people with disabilities in Western Europe. Individual countries have developed a network of institutions and services for the so-called regenerative break, which allows carers of dependent persons to regenerate their strength and to achieve a better personal balance by relieving them of their care obligations for a period of time. Although the recipient of the service is a disabled person, the main purpose of the service is to provide carers with rest opportunities, which increases their level of social functioning and allows them to better fulfill their social roles. This prevents burnout and maintains the ability to be active. Carers are the main focus of respite services.

Carers or guardians (these are usually parents (or other immediate family)) face significant restrictions in their social functioning. They experience a sense of loneliness and a lack of alternatives to providing care themselves. This creates numerous psychological, physical,

${ }^{2}$ R. Bakalarczyk, Polityka wsparcia rodzin z osobami niepetnosprawnymi. W cieniu wyroków Trybunału Konstytucyjnego i protestów społecznych, http://cejsh.icm.edu.pl/cejsh/element/bwmeta1.element. desklight-41572110-f790-484c-92f1-db5845173a14/c/R_Bakalarczyk_Polityka_wsparcia rodzin_z_osobami niepelnosprawnymi.pdf [access: 15.12.2019].

${ }^{3}$ E. Kulesza, Lokalna polityka społeczna, Centrum Rozwoju Zasobów Ludzkich, Warszawa 2013. 
economic and social burdens ${ }^{4}$. It is difficult to rely on full researchs at the moment, but in all their types there is a huge mental burden on carers.

In a situation where the vast majority of carers of people with disabilities are family members, there is an additional issue that needs to be considered - sustaining emotional relations with the person being cared for. All these factors can lead to the occurrence of caregiver stress syndrome in people who provide long-term care for an elderly or chronically ill person. This syndromehas various physical, psychosomatic and psychosocial symptoms. The syndrome is still little described in the literature, but it isthe consequence of excess duties and results in anxiety associated with care provision and permanent fatigue. At the same time, there is no doubt that the educational, social and professional development of dependent people depends largely on carers. The amount of time and work that carers spend and undertake is disproportionately greater than that of specialists. Despite this, the system of supporting people with disabilities does not yet recognise all the needs of carers ${ }^{5}$.

Analysis by the Imago Foundation, as well as the activities of government administration and local government, show a growing need to implement a respite break service in the Polish social policy system.

\section{Polish experiences}

The Respite Care Programme ${ }^{6}$ (as part of the Solidarity Fund) is addressed to local authorities at the commune and the poviat level. It offers financial support for local authorities (up to $80 \%$ of the cost of the task) to provide respite care. This can take the form of a day break, a 24-hour break, specialist counselling (psychological or therapeutic) or training (learning care, rehabilitation, nutrition $)^{7}$.

In addition, there are currently three programmes implemented under the Solidarity Fund that can support respite activities at the local level:

1) "Care services for people with disability" - 2019 edition,

2) "Care and housing centres",

3) "Personal assistant for the disabled" - 2019-2020 edition.

The Respite Care Programme is addressed to those carers or family members responsible for children with a disability certificate and/or persons with a significant degree of disability. It offers an ad hoc, short break in providing care and provides an opportunity for carers to raise their skills and knowledge in the field of care.

\footnotetext{
${ }^{4}$ A. Sadowska, Organizacja opieki nad chorym na chorobę Alzheimera w Polsce, [in:] Sytuacja osób chorych na chorobe Alzheimera w Polsce. Raport RPO, Grafpol, Warszawa 2016, pp. 42-43.

5 ,Opieka wytchnieniowa - dobre praktyki z kraju i zagranicy”, Raport z analizy efektów testowanego rozwiązania w ramach projektu: ,, Ustugi przerwy regeneracyjnej dla opiekunów niepetnosprawnych osób zależnych”, Fundacja Imago, Wrocław 2019.

6 The service is called differently abroad - it can be „respite care”, „short break”, „family relief”," regenerative break". For the purposes of the article, we adopted the phrase "Respite Care Programme". The chosen term is also used in western countries, where the service has a similar, institutional character.

7 Opieka wytchnieniowa nad niepetnosprawnymi - nowy program Ministerstwa Rodziny, ,Rzeczpospolita", 3.04.2019, https://www.rp.pl/Niepelnosprawni/304039948-Opieka-wytchnieniowa-nad-niepelnosprawnymi---nowy-program-Ministerstwa-Rodziny.html [acccess: 3.12.2019].
} 
The programme consists of three modules:

1) Module I - Respite care services provided at the beneficiary's place of residence;

2) Module II - Respite care services provided as part of a 24-hour stay in a support facility;

3) Module III - Respite care services in the form of specialist psychological or therapeutic counseling as well as care, rehabilitation and dietetics.

Local government (communes and poviats) can receive up to $80 \%$ of the costs of providing respite care services. The granting of respite care services under modules I and II requires an administrative decision (respite cares services are included in care and specialised care services).

This year 110 million zloty was allocated to the programme. Local governments submitted applications for only $1 / 5$ of this amount. In most cases, it was decided to provide short break services under Module II. In the field of social policy, the tasks and competences of local government must be harmonised with the tasks performed by government administration bodies. Shaping local social policy in the field of social assistance cannot take place in isolation from the tasks for which the government administration is responsible. Local social policy is not divorced from the concepts and programmes developed by the supreme bodies of state administration - the Council of Ministers and the minister responsible for social security issues ${ }^{8}$.

The process of decentralisation of the state has empowered self-governments - commune, poviat and voivodship - in the field of broadly understood social policy. Communal self-governments were entrusted with a very wide range of tasks in the field of social policy. Local authorities have the chance to play a role in creating the social order in their local communities.

The Imago Foundation, based in Wrocław, conducted a study that analysed the needs of carers of people with disabilities ${ }^{9}$. Actual carers are a very heterogeneous group, combined with a situation of caring for a dependent person. All carers of people with disabilities could participate in the regenerative break service project, regardless of the formal nature of the bond. Therefore, these people were in various relationships with their clients. The largest group were the parents of people with disabilities (the project involved the possibility of both parents' participation), but the caretakers of dependent people were also: grandparents, spouses, children, siblings or other close people (partners, friends).

Over $75 \%$ of all carers of dependent persons participating in the project were women. Men took care of their spouses more often than women, while women acting as mothers dominated. It is worth pointing out, however, that actual carers also included lonely fathers providing basic care for disabled children. However, women were the only carers of disabled parents or parents-in-law in the project (none of the men participating in the project was the

${ }^{8}$ E. Kulesza, op. cit., p. 38.

${ }^{9}$ Based on our own research and as part of the project "Short break services for carers of people with disability" implemented under the Operational Programme Knowledge Education Development, under the European Social Fund. For a year, this programme allowed nine institutions to research the provision of regeneration break services inspired by the experience of foreign project partners. Each institution chose the forms of service and the carers of dependent persons to research. 
guardian of their parents). The research posited that support for carers could be optimised by adapting services to the needs of individual carers. It was assumed that researching respite care services would result in:

1) changes to how regenerative break services are provided,

2) increased access to services supporting disabled people and their families, enabling independence and independent living,

3) an increase in the quality and scope of services provided to disabled persons and their carers.

For carers of people with disabilities, the process of researching the regenerative break service has:

1) allowed an assessment of the needs of carers ${ }^{10}$,

2) provided an indication of the most significant difficulties experienced by carers,

3) identified the scope of necessary support enabling regeneration of vitality,

4) indicated preferences as to how to use the respite break service,

5) measured the scope of changes in the life situation of carers using the service,

6) allowed an assessment of the service provided and its impact on the quality of life of carers.

The research also allowed ${ }^{11}$ the needs of the disabled themselves to be more fully appreciated, and provided an assessment of how the service affected their life situation.

Various forms of respite care were studied:

1) several hours stationary services,

2) stationary support with accommodation,

3) non-stationary services - in the place of residence of carers and people with disability, usually in the form of several hours of assistance several times a week,

4) weekend support,

5) support provided by the carer at his/her place of residence,

6) intervention support.

The degree and type of disability determine the situation of a disabled person and their carers. All carers physiciallyexert themselves in the care of dependents. Those carers with low levels of fitness are particularly burdened. The demand for care that requires carers to physically exert themselves significantly affects the respite care service provided by the institutions. Two types of disability dominated among those researched - neurological diseases and learning disability. However, analysis of the disability structure showed that a significant group of those recieving carewere affected by more than one type of disability (the sum of percentages of individual indications exceeded 100\% in total). Almost half of people experienced conjugated disability, which consists of two or even three factors limiting fitness. Among other things, for this reason, the vast majority of beneficiaries were people with a significant degree of disability.

${ }^{10}$ The study, to which the authors refer, was fully described in the Test Raport, it was probably one of the first of this type of research conducted on a large scale. The needs of carers concerned all spheres of life, it turned out that for the first time this group was subjected to any analysis.

${ }^{11}$ The study used a spreadsheet built by an expert team that required in-depth interviews. It was an innovative tool based on surveying the level of customer satisfaction. The study was conducted three times during the year of testing. 
Carers of a dependent person are a very heterogeneous group and have different relationships with their dependents. The largest group are the parents of people with disabilities. Carers of dependent people also include grandparents, spouses, children, siblings or other close people (partners, friends). Constant personal care for a disabled person usually endsthe professional activity of the carer. The welfare system requires carers of dependents to abandon their own career in order to receive benefits and they cannot be the recipient of retirement or disability benefits ${ }^{12}$.

A specially adapted assessment sheet helped researchers to identify the needs of carers, identify key areas and better recognise their service-related preferences. Part of the questionnaire concerned the difficulties experienced by carers in everyday life. The answers in the table below group responses according to their frequency.

\section{List of difficulties indicated by carers of persons with disabilities}

\begin{tabular}{|l|l|}
\hline Most often & 1. 24-hour care, 24-hour stay, need for constant support, need for constant attention \\
indicated & 2. Caring for a disabled person requires total sacrifice \\
3. No possibility of leaving a disabled person at home alone & 4. Fear of getting burned, falling over, doing something wrong to yourself \\
5. Help in self-service, difficulties encountered in everyday life, functioning and dressing, feeding, \\
washing, moving \\
6. Moving outside the home - delivery to classes, rehabilitation, lack of support in commuting, \\
public transport, architectural barriers \\
7. Fatigue, stress, lack of help from third parties
\end{tabular}

Carers often cannot count on effective support in their immediate environment. However, when respondents indicated that some support was available, they stated that is was provided 'sometimes', 'sporadically', 'occasionally', 'ad hoc', 'in emergency' situations.

In their assessment of their health, carers referred tophysical and mental exhaustion, lack of time to meet their own needs, including those related to their own health. Most carers declared that they had no free time for themselves.

The respite careservice is an innovative service in the Polish support system for people with disabilities and their relatives. The idea of the short break (respite care, regenerative break) is not fully realised in practice. Often, it is more focused on the person requiring care than on the carer. The respite care service provides carers with the opportunity to self-fulfilland to fulfill social roles. In its minimal form, it supports carers in fulfillingthe role of

${ }^{12}$ R. Bakalarczyk, op. cit., p. 69. 
a guardian. In its maximum form, it provides carers with physical and mental rest as well as competences needed by carers. The purpose of the regenerative break understood in this way is to provide support to those caring for a dependent person, as well as the implementation of the rights of guardians arising from the United Nations Convention on the Rights of Persons with Disabilities ${ }^{13}$.

The implementation of the respite care service helps to prevent the burnout of carers and dependents, strengthens the deinstitutionalisation ${ }^{14}$ of support, enables dependents to better function in the local environment, creates the opportunity to reduce public spending; offers dependents the opportunity to develop more fully and participate in the local environment or elsewhere.

Undeniably, one of the priorities of the state's policy is to create optimal living conditions for seniors. Care services are one form of support. Around $1 \%$ of the population over 60 years of age benefitted from care services in 2016. This figure is increasing every year. Around two million people are unable to live independently and need care. This figure is also increasing and the caring potential of the family is decreasing. Families are becoming smaller and ties are less close. This phenomenon is accompanied by the economic emigration of young people. These factors affect care tasks that non-family institutions are forced to undertake. In many cases, care services provided by municipalities are the only form of support that seniors can count on. For this reason, the level and quality of home care is important $^{15}$.

This is a pan-European tendency - the Second European Quality of Life Survey shows that, especially in the countries of Central and Eastern Europe, one can expect tensions between family life and professional work, which are caused by having caring responsibilities for an elderly person ${ }^{16}$.

${ }^{13}$ Konwencja o prawach osób niepełnosprawnych sporządzona w Nowym Jorku z 13 grudnia 2006 r., Dz. U. z 2012 r., poz. 1169.

14 J. Krzyszkowski, Deinstytucjonalizacja ustug dla seniorów jako element polityki senioralnej, Wydział Ekonomiczno-Socjologiczny, Uniwersytet Łódzki, Łódź 2018, pp. 40-45, http://cejsh.icm.edu.pl/ cejsh/element/bwmeta1.element.desklight-7363b118-9313-4de9-8faa-ce0603804c37 [access: 25.12.2019].

${ }^{15}$ Informacja o wynikach kontroli. Ustugi opiekuńcze świadczone osobom starszym w miejscu zamieszkania, KPS.430.006.2017, nr ewid. 31/2018/P/17/043/KPS, pp. 5-12.

${ }^{16}$ I.E. Kotowska, A. Matysiak, M. Styrc, A. Pailhé, A. Solaz, D. Vignoli, Second European Quality of Life Survey. Family life and work, European Foundation for the Improvement of Living and Working Conditions, Luxembourg 2010. 


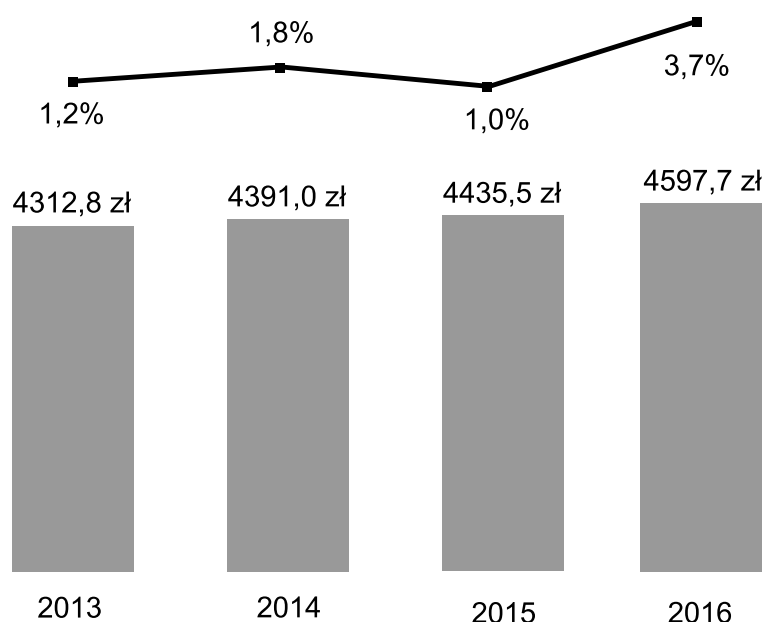

Pic. 1. Average annual cost, on a Polish scale, of supporting one elderly person in the place of residence (PLN) Source: Informacja o wynikach kontroli. Usługi opiekuńcze świadczone osobom starszym w miejscu zamieszkania, KPS.430.006.2017, nr ewid. 31/2018/P/17/043/KPS.

\section{Summary}

Poland's demography is characterised by low fertility rate and increasing life expectancy. As a result, the proportion of elderly and dependent people in our society is increasing. De-institutionalisation is the main tendency in the formal care of dependent people, including seniors who require support. In the subpopulation of seniors, the largest group (almost a third) are people aged $60-64$, but almost every fifth senior (18\%) is over 80 years old, which increases the risk of dependence and necessitates taking action for the benefit of dependent persons ${ }^{17}$.

The systemic adaptation of Western solutions, such as including caregiving families in the support system, and de-institutionalisation, will increase the sense of social security, eliminate pathological situations and skilfully prevent critical situations. Nevertheless, the inclusion of the short break service permanently in the Polish law system must be combined with ensuring system and financial stability. It is necessary to systematically control, monitor and assess needs in this area and to provide local authorities with the means to design and deliver the service.

\section{Bibliography}

Bakalarczyk R., Polityka wsparcia rodzin z osobami niepetnosprawnymi. W cieniu wyroków Trybunału Konstytucyjnego i protestów społecznych, http://cejsh.icm.edu.pl/cejsh/element/ bwmeta1.element.desklight-41572110-f790-484c-92f1-db5845173a14/c/R Bakalarczyk Polityka_wsparcia_rodzin_z_osobami_niepelnosprawnymi.pdf [access: 15.12.2019].

${ }^{17}$ J. Krzyszkowski, op. cit., pp. 1-4. 
Informacja o wynikach kontroli. Ustugi opiekuńcze świadczone osobom starszym w miejscu zamieszkania, KPS.430.006.2017, nr ewid. 31/2018/P/17/043/KPS.

Konwencja o prawach osób niepełnosprawnych sporządzona w Nowym Jorku z 13 grudnia 2006 r., Dz.U. z 2012 r., poz. 1169.

Kotowska I.E., Matysiak A., Styrc M., Pailhé A., Solaz A., Vignoli D., Second European Quality of Life Survey. Family life and work, European Foundation for the Improvement of Living and Working Conditions, Luxembourg 2010.

Krzyszkowski J., Deinstytucjonalizacja ustug dla seniorów jako element polityki senioralnej, Wydział Ekonomiczno-Socjologiczny, Uniwersytet Łódzki, Łódź 2018, http://cejsh.icm.edu.pl/ cejsh/element/bwmeta1.element.desklight-7363b118-9313-4de9-8faa-ce0603804c37 [access: 25.12.2019].

Kulesza E., Lokalna polityka społeczna, Centrum Rozwoju Zasobów Ludzkich, Warszawa 2013.

„Opieka wytchnieniowa - dobre praktyki z kraju i zagranicy”. Raport z analizy efektów testowanego rozwiąania w ramach projektu „, Usługi przerwy regeneracyjnej dla opiekunów niepetnosprawnych osób zależnych”, Fundacja Imago, Wrocław 2019.

Opieka wytchnieniowa nad niepetnosprawnymi - nowy Program Ministerstwa Rodziny, ,Rzeczpospolita", 3.04.2019, https://www.rp.pl/Niepelnosprawni/304039948-Opieka-wytchnieniowanad-niepelnosprawnymi---nowy-program-Ministerstwa-Rodziny.html [acccess: 3.12 .2019 ].

Sadowska E., Organizacja opieki nad chorym na chorobę Alzheimera w Polsce, [in:] Sytuacja osób chorych na chorobę Alzheimera w Polsce. Raport RPO, Grafpol, Warszawa 2016. 